\title{
ANALISIS PERUBAHAN HEMODINAMIKA TUBUH PADA PASIEN HIPERGLIKEMIA DENGAN TERAPI REHIDRASI DI IGD RSUD DR. ISKAK TULUNG AGUNG
}

\author{
Erik Irham Lutfi ${ }^{1}$, Titin Andri Wihastuti ${ }^{2}$, Heri Kristianto ${ }^{3}$ \\ ${ }^{1}$ Program Studi Magister Keperawatan Fakultas Kedokteran Universitas Brawijaya \\ ${ }^{2,3}$ Staf Pengajar Magister Keperawatan Fakultas Kedokteran Universitas Brawijaya \\ E-mail : erikirham85@gmail.com
}

\begin{abstract}
Disease patterns change in the World led to significant increases of non infectious diseases, one of which is DM hyperglycemia with Indonesian rank fifth in the World. Uncontrolled DM hyperglycemia will lead an increase in osmolarity that will disrupt the body's fluid and electrolyte balance. The primary management of hyperglycaemia according to ADA is by fluid rehydration therapy. Successful replacement of rehydration fluids can be seen by monitoring continuous and sustained of hemodynamics. This study aims is to analyze the changes in hemodynamics in hyperglycemia patients receiving rehydration therapy. This study included into comparative studies with a cohort approach. The number of samples in this study as many as 56 respondents. Date collection using consecutive sampling technique. From the result of the research based on the bivariate analysis test, there is no change in the hemodynamic variables with $p$ value for each hemodynamic research variable more than 0.005 ( $p$ value of pulse frequency variable $=0,825, p$ value of respiratory frequency $=0,434, p$ value of systolic blood pressure $=0,534, p$ value of oxygen saturation $=0,007$ and $p$ value of consciousness $=0,368$ ). Changes in osmolarity occur due to a decrease in blood glucose levels after fluid rehydration. This further proves that rehydration therapy is very effective in lowering blood glucose levels (hyperosmolarity) in the blood. Continuous osmolarity and hemodynamic examination is needed for hyperglycemic patients receiving rehydration therapy to determine the effect of rehydration therapy and to know the side effects of rehydration therapy so that prevention can be done to avoid problems causing emergency situations.
\end{abstract}

\section{Keywords : Rehydration Therapy, Osmolarity, Hemodynamics}

\begin{abstract}
Abstrak : Perubahan pola penyakit di dunia dengan angka penyakit tidak menular mengalami peningkatan. Penyakit tidak menular di Indonesia, yang meningkat salah satunya adalah penyakit DM dengan Indonesia berada pada peringkat ke lima di Dunia. DM Hiperglikemia yang tidak terkontrol akan menyebabkan peningkatan osmolaritas yang akan menganggu keseimbangan cairan dan elektrolit tubuh. Tatalaksana utama hiperglikemia menurut ADA adalah dengan terapi rehidrasi cairan. Keberhasilan penggantian cairan rehidrasi dapat dilihat dengan melakukan pemantauan secara berkesinambungan dan berkelanjutan. Penelitian ini bertujuan untuk menganalisis perubahan hemodinamika tubuh pada pasien hiperglikemia yang mendapatkan terapi rehidrasi. Penelitian ini termasuk kedalam penelitian komparatif dengan pendekatan cohort. Jumlah sampel dalam penelitian ini sebanyak 56 responden dengan pengambilan data menggunakan teknik consecutive sampling. Dari hasil penelitian berdasarkan uji analisis bivariat tidak terlihat perubahan pada variabel hemodinamika tubuh dengan $\mathrm{p}$ value untuk masing-masing variabel penelitian hemodinamika lebih dari 0,005 ( $p$ value variabel frekuensi nadi $=0,825, p$ value frekuensi pernapasan $=0,434, p$ value variabel tekanan darah sistolik $=0,534, p$ value variabel saturasi oksigen $=0,007$ dan $p$ value variabel kesadaran $=0,368$ ). Perubahan osmolaritas terjadi akibat adanya penurunan kadar glukosa darah setelah dilakukan rehidrasi cairan. Hal ini semakin membuktikan bahwa terapi rehidrasi sangat efektif dalam menurunkan kadar glukosa darah (hiperosmolaritas) di dalam darah. Pemeriksaan osmolaritas dan hemodinamika yang berkesinambungan sangat diperlukan bagi pasien hiperglikemia yang mendapatkan terapi rehidrasi untuk mengetahui efek terapi rehidrasi maupun untuk mengetahui efek samping dari terapi rehidrasi sehingga dapat dilakukan upaya pencegahan agar tidak menjadi permasalahan yang menimbulkan situasi kegawat daruratan.
\end{abstract}

Kata kunci : Terapi Rehidrasi, Osmolaritas, Hemodinamika

\section{PENDAHULUAN}

Perubahan pola penyakit di dunia dimana angka penyakit tidak menular mengalami peningkatan menjadi permasalahan global tidak terkecuali di Indonesia. Penyakit tidak menular di
Indonesia, yang meningkat salah satunya adalah penyakit DM dengan Indonesia berada pada peringkat ke lima di Dunia. Hiperglikemia akut disebabkan karena adanya defisiensi insulin dari dalam tubuh. 
Kadar insulin yang ada di dalam tubuh pada akhirnya tidak bisa mempertahankan kadar glukosa serum normal (horng RC et al, 2012).

Hiperglikemia selanjutnya dapat melemahkan kapasitas sekresi insulin dan menambah berat resistensi insulin sehingga membentuk lingkaran yang saling memberikan efek samping dimana hiperglikemia bertambah berat dan produksi insulin makin kurang (Augusta LA et al, 2010). Hiperglikemia yang tidak terkontrol akan menyebabkan hiperosmolaritas, adanya hiperosmolaritas menstimulasi terhadap proses diuresis osmotik dalam tubuh, sehingga cairan dan elektrolit dari intrasel keluar ke ekstrasel, perpindahan cairan ini menyebabkan sel mengalami penurunan komposisi cairan tubuh, sehingga akan menyebabkan dehidrasi (Tokuda $Y$ et al, 2010).

Hal penting tentang tata laksana manajemen hiperglikemia adalah penentuan deficit cairan tubuh yang terjadi akibat adanya hiperosmolaritas, beratnya kekurangan cairan yang terjadi yang dipengaruhi oleh durasi hiperglikemia yang terjadi, fungsi ginjal, dan intake cairan penderita (Gloria MB, 2013). Prioritas utama tata laksana hiperglikemia yang menyebabkan adanya dehidrasi adalah terapi cairan (Rehidrasi) (Kitabchi \& Ebenezer, 2016). Rehidrasi selama empat jam pertama, menunjukkan adanya penurunan kadar glukosa darah pada $80 \%$ pasien hiperglikemia (Gotera dan Bodeyasa, 2010), selanjutnya adalah menurunkan hiperglikemia dan mengatasi gangguan keseimbangan elektrolit, identifikasi komorbid yang merupakan faktor presipitasi, dan upaya monitoring ketat dan upaya pencegahan rekurensi (Augusta LA et al, 2010). Terapi cairan pada awalnya ditujukan untuk memperbaiki volume intravascular dan extravascular dan mempertahankan perfusi ginjal. Terapi cairan juga akan menurunkan kadar glukosa darah tanpa bergantung pada insulin, dan menurunkan kadarhormon kontra insulin (dengan demikian memperbaiki sensitivitas terhadap insulin) (Zeitler, P. et al, 2011).

Jenis cairan yang diberikan sesuai dengan pedoman tata laksana kegawatan hiperglikemia adalah cairan isotonik (Normal saline dengan kandungan 0,9\%
$\mathrm{NaCl})$ dengan dosis pemberian sebanyak 10-20 $\mathrm{ml} / \mathrm{kgBB} / \mathrm{jam}$ menyesuaikan dengan kondisi tubuh (fungsi jantung, pembuluh darah dan fungsi ginjal) (ADA, 2014).Pemberian larutan isotonis sangat efektif dalam pemenuhan kebutuhan cairan dari pada cairan lainnya terutama cairan isotonis nornal salin 0,9\% (Horng R.C. et all, 2012).

Prinsip tata laksana rehidrasi pada pasien hiperglikemia sesuai dengan prinsip teori keperawatan yang dikembangkan oleh Wiedenbach dengan prinsip penekanan here and now untuk menolong pasien yang membutuhkan (Alligood, M.R, 2014). Keberhasilan penggantian cairan intravaskuler dapat dilihat dengan pemantauan hemodinamik. Pemantauan hemodinamika menggunakan standar EWSS (Early Warning Scoring System) untuk melihat perubahan dari tekanan darah sistolik, frekuensi nadi, saturasi oksigen, kesadaran, produksi urin) (Diacon, A, 2012).

Penggantian cairan diharap dapat mengkoreksi defisit dalam 24 jam pertama. pemantauan hemodinamika dan osmolaritas serum dan penilaian jantung, ginjal, dan status mental harus sering dilakukan selama pemberian cairan untuk menghindari overload yang iatrogenic (Augusta L.A et al, 2012).Hal terpenting dalam koreksi hiperglikemia dengan rehidrasi cairan adalah pemantauan pasien terus menerus terkait dengan status hemodinamikanya, hal ini bertujuan untuk mencegah munculnya komplikasi akibat pemberian terapi, yaitu kelebihan volume cairan pada ekstra sel dan gangguan keseimbangan elektrolit akibat pemberian elektrolit tubuh dari luar (Bakes, K. et all, 2016.

\section{METODE PENELITIAN}

Rancangan penelitian adalah analitik komparatif dengan pendekatan cohort, jenis cohort yang di gunakan adalah cohort prospektif. Pendekatan metode ini di gunakan karena peneliti mengambil data setelah program terapi rehidrasi di berikan sampai program terapi di hentikan atau di modifikasi dengan metode lain seperti terapi rehidrasi kombinasi insulin. Pengukuran hemodinamika di lakukan sebanyak 3 kali pengukuran dengan pembagian waktu (sebelum, di dalam program terapi dan 
sesudah pemberian terapi rehidrasi diberikan). Penelitian ini di lakukan pada seluruh pasien hiperglikemia akut maupun hiperglikemia krisis yang MRS di IRD RSUD dr. Iskak Tulung agung baik diruang red zone maupun yellow zone yang mendapatkan terapi rehidrasi. Penelitian dilaksanakan bulan Juni - Juli 2017, bertempat di IGD RSUD dr. Iskak Tulung Agung. Jumlah responden dalam penelitian ini sebanyak 56 responden. Instrumen penelitian ini adalah lembar observasi. Analisa data bivariat yang digunakan penelitian ini ada 3 yaitu $T$ Paired test (osmolaritas dengan terapi rehidrasi), Repeated anova (hemodinamika / frekuensi nadi dengan terapi rehidrasi) dan friedman test (untuk hemodinamika (frekuensi pernapasan, tekanan darah sistolik, saturasi oksigen dan tingkat kesadaran).

\section{HASIL PENELITIAN}

Hasil penelitian menggambarkan karakteristik responden, terapi rehidrasi dan perubahan hemodinamika tubuh.

Tabel 1 Distribusi Usia responden Hiperglikemia

\begin{tabular}{cccc} 
& Kategori & Jumlah & $\%$ \\
\hline Usia & 31-40 tahun & 2 & 3,6 \\
& $41-50$ tahun & 19 & 33,9 \\
& $51-60$ tahun & 16 & 28,6 \\
& $61-70$ tahun & 15 & 26.8 \\
& $71-90$ tahun & 4 & 7,1 \\
\hline Total & 56 & 100 \\
\hline
\end{tabular}

Dari tabel 1 hampir setengah responden penelitian berusia diantara 41-45 tahun sebesar 33,9 \%, usia terendah responden berada pada kisaran 31-40 tahun sebanyak 3,6 responden dan terdapat 7,1 responden yang berada pada rentang usia 71-90 tahun ketika mengalami hiperglikemia.

Tabel 2 Distribusi Jenis kelamin responden Hiperglikemia

\begin{tabular}{clcc}
\hline & Kategori & Jumlah & \% \\
\hline \multirow{2}{*}{ Jenis } & Perempuan & 27 & 48,2 \\
& Laki-laki & 29 & 51,8 \\
\hline & Total & 56 & 10 \\
\hline
\end{tabular}

Dari tabel 2 diketahui bahwa sebagian besar jenis kelamin responden adalah laki-laki sebesar $51,8 \%$.

Tabel 3 Distribusi Lama Sakit DM responden

\begin{tabular}{clcc}
\hline & Kategori & Jumlah & $\%$ \\
\hline \multirow{2}{*}{ Lama Sakit DM } & 1-6 Tahun & 39 & 69,6 \\
& 6-10 Tahun & 12 & 21,4 \\
& 11-15 Tahun & 4 & 7,1 \\
& 16-20 Tahun & 1 & 1,8 \\
\hline & Total & 56 & 100 \\
\hline
\end{tabular}

Dari tabel 3 diketahui bahwa lama sakit DM 1-5 Tahun sebesar $69,6 \%$ dan ada 1,8\% responden yang memiliki riwayat lama sakit DM 16-20 Tahun. 
Tabel 4 Distribusi jumlah terapi rehidrasi

\begin{tabular}{ccc}
\hline Jumlah Terapi Rehidrasi & $\mathbf{n}$ & $\%$ \\
\hline $500 \mathrm{ml}$ & 7 & 12,5 \\
$1000 \mathrm{ml}$ & 46 & 82,1 \\
$2500 \mathrm{ml}$ & 2 & 3,6 \\
$3000 \mathrm{ml}$ & 1 & 1,8 \\
Total & 56 & 100 \\
\hline
\end{tabular}

Berdasarkan tabel 4, diketahui jumlah hampir seluruh responden mendapatkan terapi rehidrasi sejumlah $1000 \mathrm{ml}$ selama program terapi rehidrasi.

Grafik 1. Perbedaan rerata frekuensi nadi sebelum, selama dan sesudah terapi rehidrasi

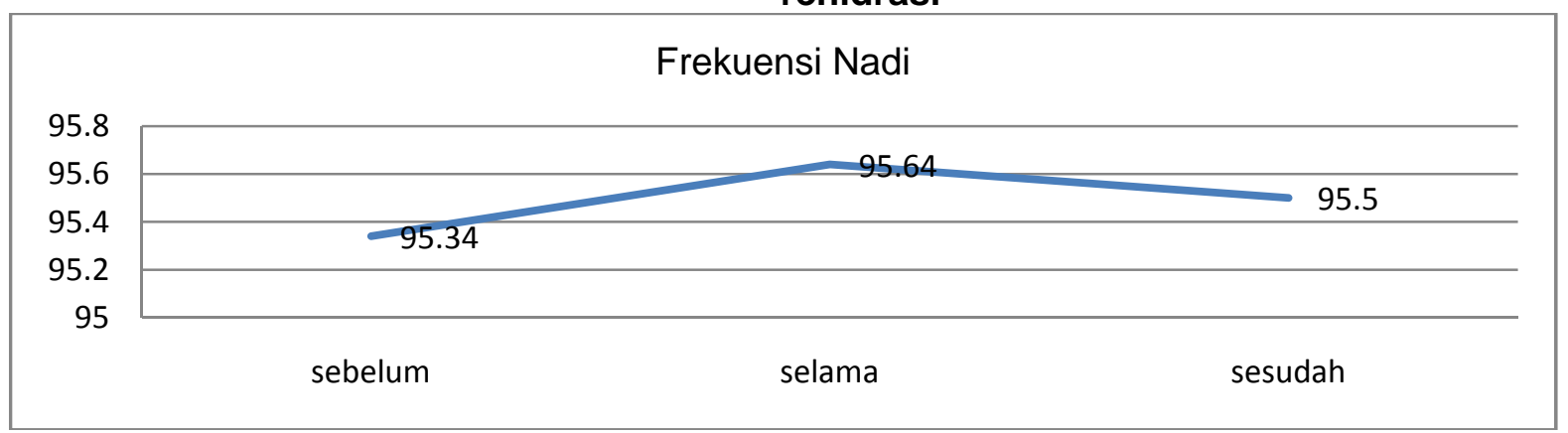

Berdasarkan grafik 1, didapatkan perbedaan tidak signifikan rerata frekuensi nadi dimana pada ketiga pengukuran berada pada rentang 95-96x/menit.

Grafik 2. Perbedaan frekuensi pernapasan sebelum, selama dan sesudah terapi rehidrasi

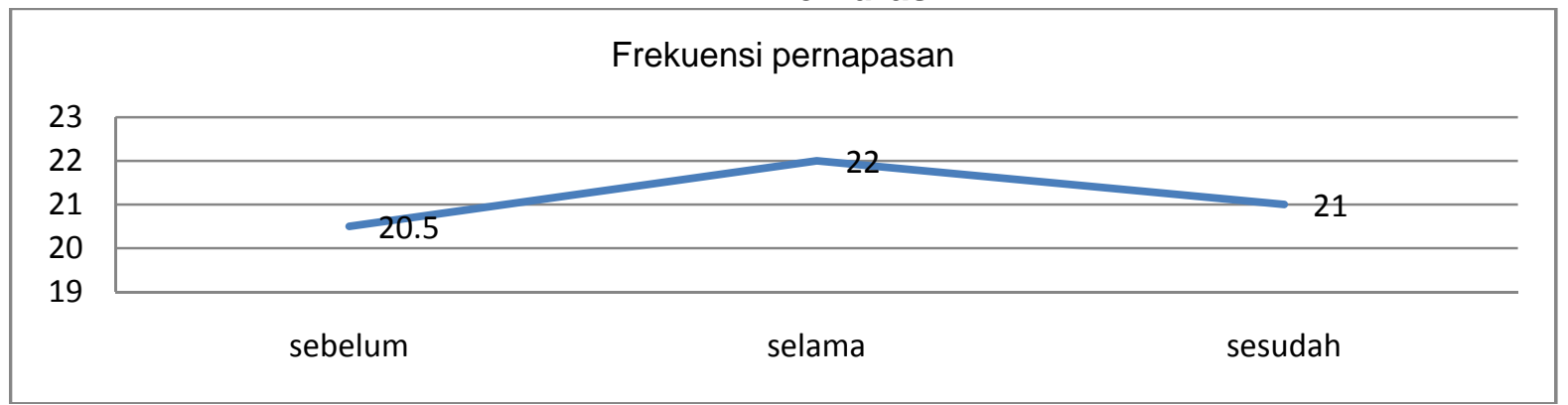

Berdasarkan grafik 2, didapatkan perbedaan tidak signifikan rerata frekuensi pernapasan dimana pada ketiga pengukuran berada pada rentang 20-22x/menit.

Grafik 3. Perbedaan tekanan darah sistolik sebelum, selama dan sesudah terapi rehidrasi

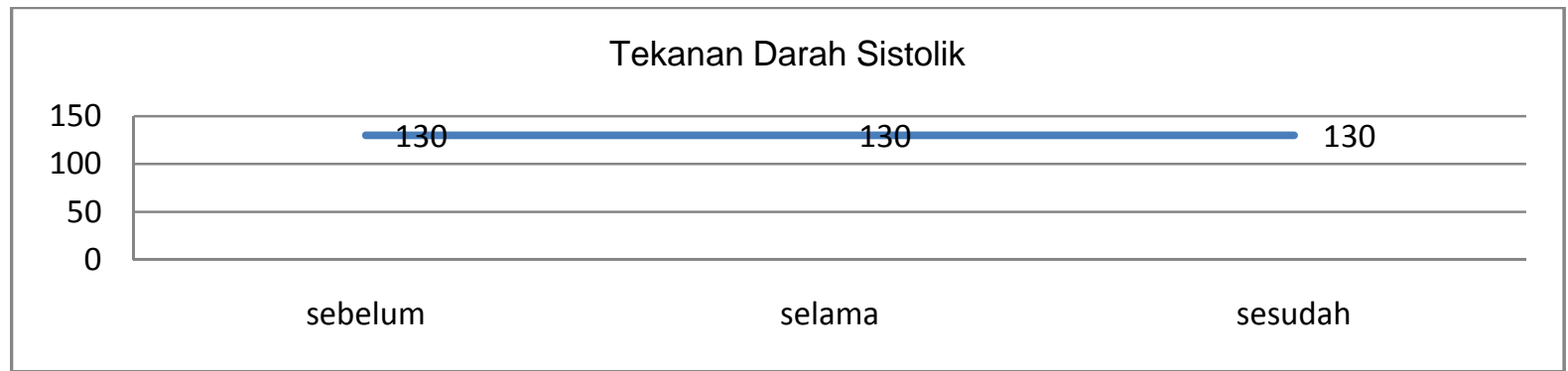


Berdasarkan grafik 3, didapatkan tidak terdapat perbedaan tekanan darah sistolik pada ketiga pengukuran dimana hasilnya sama berada pada $130 \mathrm{mmHg}$.

Grafik 4. Perbedaan saturasi oksigen sebelum, selama dan sesudah terapi rehidrasi

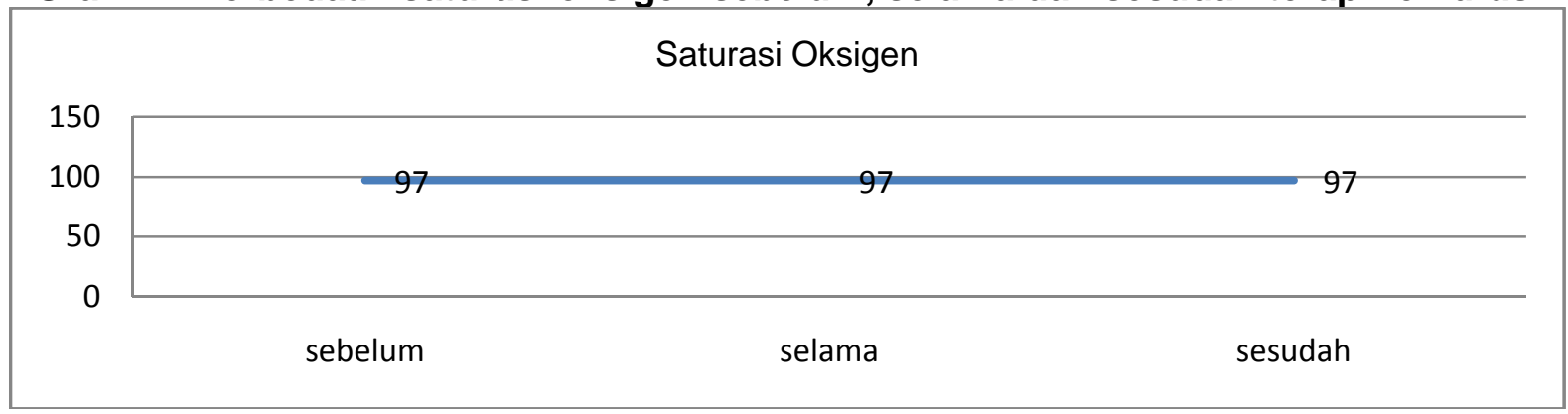

Berdasarkan grafik 4, didapatkan tidak terdapat perbedaan saturasi oksigen pada ketiga pengukuran dimana hasilnya sama berada pada $97 \%$.

Grafik 5. Perbedaan kesadaran sebelum, selama dan sesudah terapi rehidrasi

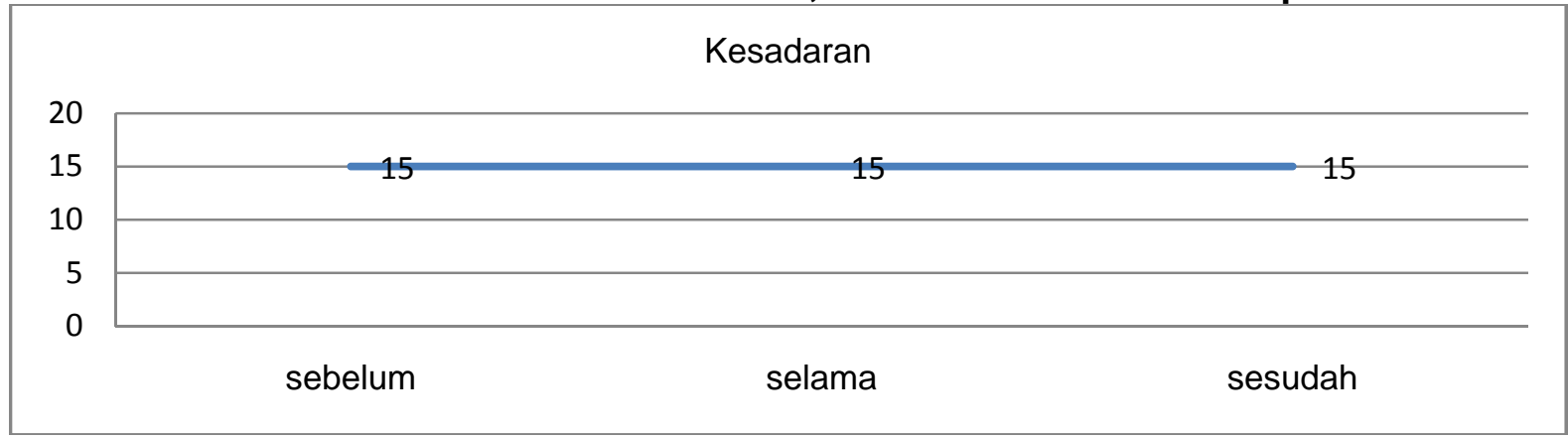

Berdasarkan grafik 5, didapatkan tidak terdapat perbedaan kesadaran pada ketiga pengukuran dimana hasilnya sama berada pada 15 (Compos mentis/sadar penuh).

Tabel 5 hasil analisis bivariat perubahan hemodinamika (Frekuensi Nadi) sebelum, selama dan sesudah terapi rehidrasi

\begin{tabular}{lccccc}
\hline \multirow{2}{*}{ Jenis Variabel } & Perlakuan & N & Mean & SD & P Value \\
& & Sebelum & 56 & 94,8 & 15,8 \\
\cline { 2 - 4 } Frekuensi nadi & Selama & 56 & 95,6 & 13,2 & \\
\cline { 2 - 5 } & Sesudah & 56 & 95,5 & 12,5 & \\
\hline
\end{tabular}

Berdasarkan tabel 5 menunjukkan $p$-value hasil analisis bivariat 0,825 dimana $p$ value $>0,005$, hal ini membuktikan tidak terdapat perbedaan frekuensi nadi selama 3 kali pengukuran. 
Tabel 6. Hasil analisis bivariat perubahan hemodinamika (frekuensi pernapasan, tekanan darah sistolik, saturasi oksigen dan kesadaran) sebelum, selama dan sesudah terapi rehidrasi

\begin{tabular}{|c|c|c|c|c|}
\hline Jenis Variabel & Perlakuan & $\mathbf{N}$ & $\begin{array}{c}\text { Median } \\
\text { (Min-max) }\end{array}$ & $P$ Value \\
\hline \multirow{3}{*}{ Frekuensi Pernapasan } & Sebelum & 56 & $20,5(17-30)$ & \multirow{3}{*}{0,434} \\
\hline & Selama & 56 & $22(16-33)$ & \\
\hline & Sesudah & 56 & $21(17-30)$ & \\
\hline \multirow{3}{*}{ Tekanan darah sistolik } & Sebelum & 56 & $130(90-170)$ & \multirow{3}{*}{0,534} \\
\hline & Selama & 56 & $130(87-225)$ & \\
\hline & Sesudah & 56 & $130(100-203)$ & \\
\hline \multirow{3}{*}{ Saturasi oksigen } & Sebelum & 56 & 97 (91-99) & \multirow{3}{*}{0,072} \\
\hline & Selama & 56 & 97 (91-99) & \\
\hline & Sesudah & 56 & 97 (92-99) & \\
\hline \multirow{3}{*}{ Kesadaran } & Sebelum & 56 & $15(9-15)$ & \multirow{3}{*}{0,368} \\
\hline & Selama & 56 & $15(9)$ & \\
\hline & Sesudah & 56 & $15(9)$ & \\
\hline
\end{tabular}

Berdasarkan tabel 6 menunjukkan p-value hasil analisis bivariat masing - masing variabel dari hemodinamika (frekensi pernapasan, tekanan darah sistolik, saturasi

\section{PEMBAHASAN}

1. Perubahan hemodinamika pada pasien hiperglikemia sebelum, sesaat dan sesudah terapi rehidrasi

Penilaian hemodinamika meng-adopsi dari EWSS (Early Warning Scoring System). Berdasarkan hasil penelitian hemodinamika selama penelitian (3 kali pengukuran) nilai hemodinamika berada dalam rentang normal dengan kenaikan pada level pertama (rentang warna hijau) berdasarkan indikator EWSS, dimana frekuensi nadi mean berada pada kisaran 94-96 x/menit (Normal 51-90), sedangkan median dari frekuensi pernapasan 2022x/menit (Normal 12-20), tekanan darah sistolik $130 \mathrm{mmHg}$ (Normal 100-179), saturasi oksigen 97\% (Normal >95\%), dan kesadaran 15 (Normal 15/Compos mentis).

Berdasarkan hasil penelitian didapatkan hemodinamika normal pada penelitian ini sesuai dengan kriteria hasil oksigen dan kesadaran) $>0,005$, hal ini membuktikan tidak terdapat perbedaan dari masing-masing variabel selama 3 kali pengukuran.

diagnosa keperawatan resiko ketidakseimbangan elektrolit dan resiko kekurangan volume cairan tubuh yaitu tanda-tanda vital dalam batas normal dan tidak muncul tanda-tanda terjadinya peningkatan jumlah cairan didalam paruparu (frekuensi pernapasan dalam rentang normal) dan tanda edema serebral (kesadaran $=$ compos mentis). Tidak adanya perubahan signifikan dari hemodinamika (frekuensi nadi, frekuensi pernapasan, tekanan darah sistolik, saturasi oksigen dan kesadaran) dalam penelitian ini dimana nilai $P$ value $>0,005$ di jelaskan sebagai berikut :

\subsection{Perubahan frekuensi nadi sebelum, selama dan sesudah terapi rehidrasi \\ Tidak adanya perubahan signifikan frekuensi nadi pada penelitian ini disebabkan beberapa faktor antara lain : pertama, responden tidak berada dalam kondisi dehidrasi dengan salah satu}


tandanya adalah peningkatan nadi dimana mean nadi dalam penelitian ini berada pada rentang 51-100 x/menit. Penyebab yang kedua meskipun terdapat perubahan bermakna pada $16 \%$ responden, tetapi tidak cukup kuat mewakili $84 \%$ responden dengan rentang normal, sehingga hasil mean tetap dalam rentang 51-100x/menit.

Hasil penelitian yang sama ditemukan di RS Okinawa pada responden hiperglikemia tanpa komplikasi dimana frekuensi nadi berkisar pada angka 92x/menit. Hal ini mempertegas bahwa pasien hiperglikemia yang tidak mengalami komplikasi frekuensi nadi akan cenderung Normal (Leksana, 2015).

\subsection{Perubahan frekuensi pernapasan sebelum, selama dan sesudah terapi rehidrasi \\ Tidak adanya perubahan signifikan} frekuensi pernapasan pada penelitian ini sebagai tanda adanya komplikasi akibat terapi rehidrasi pada 1-2 jam ditandai dengan rentang frekuensi pernapasan dalam penelitian ini berada pada kategori normal semakin membuktikan terapi $10-20$ $\mathrm{ml} / \mathrm{kgBB} / \mathrm{Jam}$ selain efektif untuk menurunkan kadar gula darah sewaktu, juga tidak menimbulkan efek samping munculnya edema paru. Penyebab tidak adanya perubahan signifikan ini disebabkan karena tidak adanya tanda-tanda penurunan perfusi jaringan, dikarenakan tidak adanya penurunan perfusi jaringan dapat diketahui dengan frekuensi napas tetap dalam rentang normal dimana median antara 20 - 22x / menit. Normalitas frekuensi pernapasan ini ditemukan juga pada responden penelitian di RS Okinawa Jepang pada pasien hiperglikemia tanpa komplikasi dimana mean frekuensi pernapasan pada rentang 22x/menit (Leksana, 2015).

\subsection{Perubahan tekanan darah sistolik sebelum, selama dan sesudah terapi rehidrasi}

Tidak adanya perubahan/perbedaan signifikan tekanan darah sistolik dalam penelitian ini dimana responden tidak masuk kedalam kondisi dehidrasi meskipun responden mengalami hiperglikemia (mean tekanan darah berada pada 528,61) dimana tanda dehidrasi salah satunya adalah penurunan tekanan darah sistolik, dimana median tekanan darah pada penelitian ini berada dalam normotensi (130 $\mathrm{mmHg}$ ), normotensi menandakan daya dorong darah pada pembuluh darah masih adekuat sehingga mampu mengalirkan darah dan isinya menuju ke seluruh tubuh untuk melakukan aktifitas metabolisme di sel. Adekuatnya jumlah darah dan pembuluh darah pada responden penelitian ini, memungkinkan tubuh akan melakukan kompensasi terhadap cairan yang masuk kedalam tubuh, hal ini di buktikan dengan terapi rehidrasi $10-20 \mathrm{ml} / \mathrm{kgBB} / \mathrm{jam}$ yang diberikan pada responden, tidak menimbulkan dampak signifikan terjadinya peningkatan beban kerja jantung yang ditandai dengan hipertensi, hal ini terbukti dimanamedian tekanan darah pada penelitian ini pada rentang $130 \mathrm{mmHg}$.

Dalam penelitian ini sebenarnya terjadi perubahan signifikan tekanan darah sistolik pada responden yang mendapatkan terapi rehidrasi antara 2500-3000 ml. Tetapi hal ini tidak signifikan dalam penelitian, dikarenakan jumlah responden yang mengalami perubahan signifikan ini dalam jumlah kecil, sehingga tidak berdampak signifikan setelah dilakukan uji analisis. Tidak adanya perbedaan tekanan darah sistolik pada responden hiperglikemia tanpa komplikasi dalam penelitian ini sesuai dengan penelitian yang dilakukan oleh Tokudo et al (2010) di RS Okinawa dimana tekanan darah sistolik responden penelitian berkisar antara $138 \mathrm{mmHg}$. Hal ini dapat disimpulkan terapi rehidrasi 10-20 $\mathrm{ml} / \mathrm{kgBB} / \mathrm{jam}$ pada jam ke 1-2 tidak menimbulkan efek samping terhadap tekanan darah dan jantung pasien hiperglikemia.

\subsection{Perubahan saturasi oksigen sebelum, selama dan sesudah terapi rehidrasi \\ Tidak adanya perbedaan signifikan} saturasi oksigen pada penelitian ini disebabkan karena kondisi pasien dalam penelitian ini tidak ditemukan permasalahan pada sistem respirasi, dimana tanda dari permasalahan respirasi adanya peningkatan frekuensi pernapasan, hal ini dapat di buktikan dengan median frekuensi pernapasan pada penelitian ini pada rentang 20-22x/menit. Ketiadaan permasalahan sistem respirasi dalam penelitian ini di buktikan dengan mean 
frekuensi nadi dalam penelitian ini berada dalam kategori normal (97x/menit), dimana terjadi permasalahan pada sistem respirasi nadi akan bersinergi dengan berupaya meningatkan kerja di tandai dengan peningkatan nadi (Tachycardia) sebagai upaya membawa kandungan oksigen lebih sering untuk mencukupi kebutuhan sel didalam tubuh dan membuang karbondioksida dari dalam tubuh yang dikeluarkan melalui ekspirasi ketika bernapas.

\subsection{Perubahan kesadaran sebelum, selama dan sesudah terapi rehidrasi \\ Tidak adanya perubahan signifikan} terapi rehidrasi terhadap kesadaran dimana median kesadaran responden penelitian ini berada pada rentang 15 (compos mentis I sadar penuh). Kesadaran yang maksimal menandakan tidak adanya efek samping berupa edema cerebral yang ditimbulkan akibat terapi rehidrasi pada penelitian ini dimana indikator adanya edema serebral adalah penurunan kesadaran.Didalam penelitian ini, didapatkan data terapi cairan tidak spesifik merubah kesadaran sesorang, dimana dalam penelitian ini, beberapa responden yang sebelum terapi sudah mengalami penurunan kesadaran, setelah diberikan terapi 10-20 ml/kgBB/jam pada 12 jam pertama, kesadaran tetap menurun dan tidak berubah. Penurunan keadaran pada peneilitian kali ini ditemukan pada pasien hiperglikemia yang mengalami komplikasi akut dan masuk kedalam kondisi KAD (Keto Asidosis Diabetikum) maupun HHS (Hiperosmolarity Hiperglicemya state).

\section{Implikasi teori Keperawatan Weidenbach pada pasien Hiperglikemia}

Kondisi hiperglikemia akan memicu peningkatan osmolaritas dalam tubuh dan ini akan menganggu konsentrasi cairan didalam tubuh. Sesuai dengan algoritma ADA 2014 terapi cairan merupakan terapi awitan dan utama dalam upaya menurunkan hiperglikemia pada fase akut. Pengembalian cairan tubuh akan meningkatkan homeostatis tubuh. Pemberian cairan pada fase akut terutama pada 2 jam pertama setelah pasien MRS sesuai dengan konsep keperawatan "need for help" yang kegiatan utamanya berprinsip kepada "here and now" yang dikembangkan oleh weidenbach sejak tahun 1963.

Kegiatan rehidrasi merupakan kegiatan intervensi keperawatan yang masuk kedalam diagnosa keperawatan resiko kekurangan volume cairan tubuh yang kriteria hasilnya berupa terjadinya keseimbangan cairan dan elektrolit dalam tubuh.

Pentingnya terapi rehidrasi pada fase akut, harus diimbangi dengan monitoring secara berkesinambungan untuk menilai keberhasilan terapi maupun upaya pencegahan munculnya masalah akibat pemberian terapi rehidrasi. Monitoring hemodinamika dan osmolaritas yang berkesinambungan sejalan dengan intervensi keperawatan manajemen keseimbangan cairan tubuh berupa memonitor tanda-tanda vital dalam diagnosa keperawatan resiko ketidak stabilan elektrolit ${ }^{6}$.

\section{KETERBATASAN PENELITIAN}

Dalam penelitian ini, keterbatasan yang ditemukan peneliti antara lain : ada variabel yang direncanakan untuk dilakukan penelitian tetapi tidak bisa dilakukan pengambilan data yaitu variabel hemodinamika urine output. Keterbatasan peneliti dalam mengambil data pada variabel ini di sebabkan beberapa hal sebagai berikut : 1 . Responden penelitian tidak ada indikasi dilakukan pemasangan kateter, hal ini disebabkan $81 \%$ responden berada dalam kondisi kesadaran compos mentis / sadar penuh. 2. Pengukuran manual menggunakan gelas ukur berdasarkan urin tampung tidak bisa dilakukan, dikarenakan responden sebagian besar terpasang diapers (popok dewasa), sehingga urin tertampung didalam diapers dan tidak bisa dilakukan pengukuran. Keterbatasan yang kedua adalah keterbatasan waktu dalam penelitian dan jumlah responden, sehingga penelitian ini belum bisa mewakili dari seluruh responden.

\section{KESIMPULAN}

Berdasarkan hasil penelitian Analisis perubahan osmolaritas dan hemodinamika tubuh pada pasien hiperglikemia dengan terapi rehidrasi dapat disimpulkan ;1) Ada perubahan osmolaritas 
tubuh pada pasien hiperglikemia sebelum dan sesudah terapi rehidrasi, 2. Tidak terdapat perubahan frekuensi nadi pada pasien hiperglikemia sebelum, selama dan sesudah terapi rehidrasi, 3. Tidak terdapat perubahan frekuensi pernapasan pada pasien hiperglikemia sebelum, selama dan sesudah terapi rehidrasi, 4. Tidak terdapat perubahan tekanan darah sistolik pada

\section{SARAN}

\section{Pelayanan Keperawatan}

Adanya penurunan signifikan osmolaritas (kadar gula darah) akibat terapi rehidrasi dalam penelitian ini, diharapkan semua instansi kesehatan melakukan manajemen rehidrasi sebagai terapi awitan dalam manajemen kegawatdaruratan DM hiperglikemia. Bagi petugas kesehatan di layanan kegawat daruratan, hendaknya selalu melakukan monitoring hemodinamika pada pasien DM Hiperglikemia dengan terapi rehidrasi meskipun dari hasil penelitian tidak terdapat perubahan signifikan dari indikator hemodinamika tubuh karena banyak faktor seperti peneliti jelaskan sebelumnya.

\section{Ilmu Keperawatan}

Hendaknya lebih mengembangkan metode pengkajian preventife dalam upaya mengetahui efek terapi rehidrasi,sehingga perawat akan selalu berada dalam kondisi

\section{DAFTAR PUSTAKA}

ADA (2014).Diagnosis and Classification of Diabetes Mellitus.Diabetes CareVolume 37, Supplement 1, January 2014 Hal.S81-590.

Alligood, M.R (2014). Nursing Theorists And Their Work, Eighth Edition. Elsevier Mosby.

Augusta L. A et al, (2010).Krisis hiperglikemia pada diabetes melitus.Jurnal Penyakit Dalam.

Bakes, K. et all.(2016). Effect of volume of fluid resuscitation on metabolic normalization In children presenting in diabetic ketoacidosis: a randomized Controlled trial. The Journal of Emergency Medicine, Vol. 50, No. 4, pp. 551-559. pasien hiperglikemia sebelum, selama dan sesudah terapi rehidrasi, 5. Tidak terdapat perubahan saturasi oksigen pada pasien hiperglikemia sebelum, selama dan sesudah terapi rehidrasi dan 6. Tidak terdapat perubahan kesadaran pada pasien terdapat perubahan kesadaran pada pasien hiperglikemia sebelum, selama dan sesudah terapi rehidrasi.

waspada meskipun kondisi pasien dalam rentang normal. Hendaknya dalam melakukan evaluasi dari tatalaksana keperawatan menyesuaikan dengan kriteria hasil dari diagnosa keperawatan sehingga mempunyai tolok ukur keberhasilan program intervensi yang dilakukan.

\section{Peneliti Selanjutnya}

Hendaknya lebih meningkatkan jumlah responden dan waktu penelitian serta menambah responden berupa pasien DM hiperglikemia yang mengalami komplikasi berupa KAD atau HHS karena perubahan hemodinamika sangat signifikan terjadi pada responden KAD maupun HHS.Hendaknya lebih memperluas cakupan hemodinamika yang akan di teliti, misalkan membandingkan pengukuran tekanan darah, nadi antara ekstrimitas atas atau bawah dan perubahan posisi yang terjadi (duduk, bangun atau terlentang).

Diacon, A. (2012). Fluid balance monitoring in critically ill patients. Stellenbosch University.http://scholar.sun.ac.az

Gloria M. Bulechek, (et al).2013. Nursing Interventions Classifications (NIC) 6th Edition. Missouri: Mosby Elsevier.

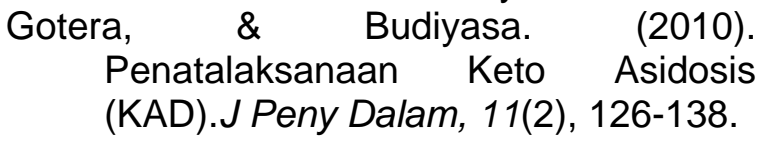

Horng. R.C. et all.(2012). Plasma-Lyte 148 vs $0.9 \%$ saline for fluid resuscitation in diabetic ketoacidosis. Journal of Critical Care)27, hal. 138-145.

Kitabchi \&Ebenezer (2016). The evolution of diabetic ketoacidosis: An update of its etiology, pathogenesis and 
management. Elsevier Inc. http://dx.doi.org/10.1016/j.metabol.201 $\underline{5.12 .007}$

Leksana, E (2015). Strategi terapi cairan pada dehidrasi.CDK-224, 42, 1.

Tokuda, $Y$ et al. (2010). Vital sign triage to rule out diabetic ketoacidosis and nonketotic hyperosmolar syndrome in hyperglycemic patients. diabetes research and clinical practice 87 hal. 366-371.
Zeitler, P. et al (2011). Hyperglycemic Hyperosmolar Syndrome in Children: Pathophysiological Considerations and Suggested Guidelines for Treatmen. The Journal of Pediatrics.www.jpeds.com, 158: no. 1. 